\title{
Resource value affects territorial defense by Broad-tailed and Rufous hummingbirds
}

\author{
Alaine F. Camfield ${ }^{1}$ \\ School of Natural Resources and Environment, University of Michigan, Dana Building, 430 E. University, Ann Arbor, \\ MI, 48109-1115, USA
}

Received 3 February 2005; accepted 14 September 2005

\begin{abstract}
Territorial behavior of Broad-tailed (Selasphorous platycercus) and Rufous (Selasphorous rufus) hummingbirds in Colorado was measured at sites with feeders containing $10 \%, 20 \%$, and $30 \%$ sucrose solutions, respectively. The presence or absence of territory holders, number of intruders, and intensity of defense were measured at the three levels of energy availability. Migrating Rufous Hummingbirds displaced Broad-tailed Hummingbirds from territories they had defended during the breeding season; Broad-tailed Hummingbirds then defended only lower quality sites. Both Broad-tailed and Rufous hummingbirds employed more energetically expensive behaviors when defending high quality sites, with longer chases more often supplemented with chip calls and hovering. Other investigators have suggested that chip calls and hovering are precursors to a chase. However, I found that chasing was the default response to the presence of an intruder. Chip calls and hovering were added to intensify a chase. In the few cases where chip calls were uttered or hovering occurred without a chase, Rufous Hummingbirds were more likely to exhibit this behavior than Broad-tailed Hummingbirds.
\end{abstract}

SINOPSIS. El valor de los recursos afecta la defensa de territorios en Selasphorous platycercus y Selasphorous rufus

La conducta territorial de los zumbadores Selasphorous platycercus y S. rufus fue medida en dos localidades de Colorado, en donde se les proveyó a las aves con libadores artificiales que contenían concentraciones de 10\%,20\% y $30 \%$ de azúcar. La presencia o ausencia de individuos que establecieron un territorio, número de intrusos y la defensa del territorio fue medido en los tres niveles de disponibilidad de fuentes de energía. Individuos migratorios de S. rufus desplazaron a individuos de la segunda especie que habían defendido dichos territorios durante la época de reproducción. S. platycercus se dedicó a defender lugares de poca calidad. Ambas especies de zumbadores emplearon conducta más agresiva y de mayor gasto energético, como persecuciones más prolongadas y uso de sonidos, cuando defendieron lugares con alta calidad. Algunos estudios han encontrado que previo a una persecución, los zumbadores producen sonidos con sus alas y otros vocales. Sin embargo, encontré que la persecución era la respuesta inmediata a la presencia de un intruso. Los sonidos eran añadidos como medio de intensificación de la persecución. En la minoría de los casos en donde los sonidos se produjeron sin que hubiera una persecución, se encontró que $S$. rufus fue más propenso a utilizar esta conducta que S. platycercus.

Key words: Broad-tailed Hummingbird, food quality, Rufous hummingbird, Selasphorous platycercus, Selasphorous rufus, territorial defense

Territoriality in most hummingbirds centers on a food source (Johnsgard 1997). Territories are vigorously defended by owners who employ energetically expensive behaviors to exclude intruders (Powers and Conley 1994). The cost-benefit approach to understanding the economics of territoriality has been useful in studies of hummingbirds and other nectivorous birds (Krebs and Davies 1993). When the costs of defending a territory outweigh the benefits of exclusive use, territorial behavior ceases (Brown

\footnotetext{
${ }^{1}$ Current address: Centre for Applied Conservation Research, Forest Sciences Centre, University of British Columbia, 2424 Main Mall, Vancouver, B.C.,V6T 1Z4, Canada. Email: camfield@interchange.ubc.ca
}

1964). For instance, if the number of intruders is too high, an owner will spend more energy on defense than they gain from the resource.

Territorial defense by hummingbirds can involve chases, vocalizations, hovering displays, and attacks. As territory quality changes, individuals may shift their form of defense (Ewald and Carpenter 1978, Ewald and Bransfield 1987). A higher quality territory may allow an owner to employ a more energetically expensive form of defense while maintaining a net energetic gain. Powers (1987) found that male Anna’s Hummingbirds (Calypte anna) spent more time chasing intruders as sucrose concentration was increased on their territories, and Dearborn (1998) found that the intensity of territorial 
defense was higher during periods of resource supplementation. Intruder pressure and competition for a food source should also increase with the value of the defended resource (Powers 1987, Marchesseault and Ewald 1991). An increased level of defense by a territory owner may be the result of increased external pressure, increased energy availability, or both.

Hummingbirds are ideal subjects for studies of the economics of territorial defense. They are very territorial and, given their high metabolic rate, respond quickly to changes in resource quality. It is also easy to quantify and manipulate the quality of their food source (Ewald and Bransfield 1987, Armstrong 1992). I studied the territorial behavior of Broad-tailed (Selasphorous platycercus) and Rufous (Selasphorous rufus) hummingbirds at feeders with three different concentrations of sugar solutions: $10 \%, 20 \%$, and 30\% sucrose (weight/volume). I measured the presence or absence of territorial behavior, intruder pressure, and the intensity of defense. I predicted that territorial behavior, intruder pressure, and the intensity of defense would be greater at feeders with higher sucrose concentrations. Further, I expected migrant Rufous Hummingbirds to displace resident Broad-tailed Hummingbirds when they were present on my study area.

Broad-tailed Hummingbirds breed throughout east-central Colorado from May to September (Calder and Calder 1992), and Rufous Hummingbirds migrate through this area in July and August as they return to wintering areas in southern Mexico (Calder 1993). Both male and female Rufous Hummingbirds are able to displace male Broad-tailed Hummingbirds from their territories (Kodric-Brown and Brown 1978, Kuban and Neill 1980). The superior competitive abilites of Rufous Hummingbirds may be due to greater high-speed maneuverability associated with high wing loading ratios (Feinsinger and Chaplin 1975, Calder 1993, Dearborn 1998). The displacement of subordinate hummingbird species by dominant species is well documented (Kodric-Brown and Brown 1978, Powers and Conley 1994, Sandlin 2000).

\section{METHODS}

I studied hummingbirds in the Gunnison National Forest in Gunnison County, Colorado, approximately $4 \mathrm{~km}$ from the Rocky Mountain Biological Laboratory (RMBL) in Gothic, Colorado (2900 m elevation; $\left.38^{\circ} 58^{\prime} \mathrm{N}, 106^{\circ} 59^{\prime} \mathrm{W}\right)$. The area surrounding the RMBL is a mix of subalpine meadows, aspen (Populus tremuloides) stands, and riparian corridors of Engelmann Spruce (Picea engelmanni) and subalpine fir (Abies lasiocarpa; Calder et al. 1983). I placed nine feeders (No. 215 Hummingbird Feeder, Perky-Pet Products Co., Denver, CO) at least $50 \mathrm{~m}$ apart along a $1-\mathrm{km}$ route on the east side of the valley. Each feeder was placed near running water, either on the edge or middle of an open meadow next to willows (Salix spp.) or conifers. I attempted to establish sites in areas with equivalent levels of natural food sources, for example, similar vegetation composition and equal size patches of flowering plants such as scarlet gilia (Ipomopsis aggregata) and Indian paintbrush (Castilleja spp.) commonly used by foraging hummingbirds.

The study took place from 28 May 2001 to 6 August 2001. I set up feeders on 28 May and data were first recorded on 30 May. Feeders held 100 $\mathrm{ml}$ of solution and had only one feeding opening and no perch so birds had to hover while feeding. I hung feeders on metal poles $1.5 \mathrm{~m}$ above the ground. I assigned sucrose concentrations (10\%, 20\%, and 30\% weight/volume) to sites randomly, with sites 1,4 , and 6 assigned $10 \%$ sucrose solutions, sites 3, 8, and 9 assigned $20 \%$ sucrose solutions, and sites 2, 5, and 7 assigned $30 \%$ sucrose solutions. Feeders were normally not emptied by the hummingbirds during the day, but I emptied and refilled each feeder daily to prevent sucrose concentrations from increasing as a result of evaporation.

I observed feeders daily for $1 \mathrm{~h}$ between 06:30 and 14:00 at each site. Observations were made 6-7 $\mathrm{m}$ from the feeders. Sites $1-5$ were observed on $1 \mathrm{~d}$, and sites $6-9$ the next. I rotated the time of observation at each feeder to avoid temporal associations of activity levels and control for diurnal variation in territorial defense behavior. Due to inclement weather, sites with feeders containing 30\% sucrose solutions could not be visited on two occasions.

I recorded the presence or absence of territorial individuals at each site. I considered a site to be defended if a single hummingbird fed at the feeder, perched nearby, and chased other hummingbirds (intruders) that entered the area. Defense behaviors included chip calls, hovering, 
chasing, or attacking other hummingbirds. I also recorded the number of intrusions per observation period, and the species and sex of each intruder. If a territory owner was present, I recorded the duration (in seconds) of each chase and noted whether the defending hummingbird uttered chip calls, hovered, or attacked the intruder. Because Rufous Hummingbirds migrate through the area and generally only stop for 12 weeks while en route (Gass 1979, Carpenter et al. 1983), it is unlikely that all observations at a single feeder were of the same individual.

Several dependent variables used in the analysis were not normally distributed. The counts of number of intruders, number of chases, and the number of chip calls and hovers were modeled using a negative binomial distribution that is appropriate for nonnormal count data (Gardner et al. 1995). Because I made repeated observations at the same sites, the analysis took into account the lack of independence of observations from the same site using Generalized Estimating Equations (GEE; Diggle et al. 1994). A binomial distribution and GEE were used to model the counts of chipping and hovering, with and without chasing. Results of GEE analysis are reported as $\chi^{2}$ values. GEE allowed for post hoc comparisons of the three treatments. Where post hoc comparisons were made, the Bonferroni correction for multiple comparisons was used and alpha was set at 0.02 . For all other analyses, alpha was set at 0.05 . Values are reported as mean \pm 1 SE. All analyses were conducted using Proc Genmod in SAS release 8.2 for Windows (SAS Institute Inc 2001).

\section{RESULTS}

When Rufous Hummingbirds arrived in the valley, they displaced male Broad-tailed Hummingbirds that had been defending sites during the breeding season. Both male and female Rufous Hummingbirds defended feeders with $30 \%$ and $20 \%$ sucrose solutions and, occasionally, feeders with $10 \%$ sucrose solutions. Although male Broad-tailed Hummingbirds defended feeders with $10 \%, 20 \%$, and $30 \%$ sucrose solutions before the arrival of the $\mathrm{Ru}$ fous Hummingbirds, within $7 \mathrm{~d}$ of the arrival of Rufous Hummingbird, male Broad-tailed Hummingbirds defended only feeders with $10 \%$ sucrose solutions. During 55 observation periods, territorial individuals were present 52

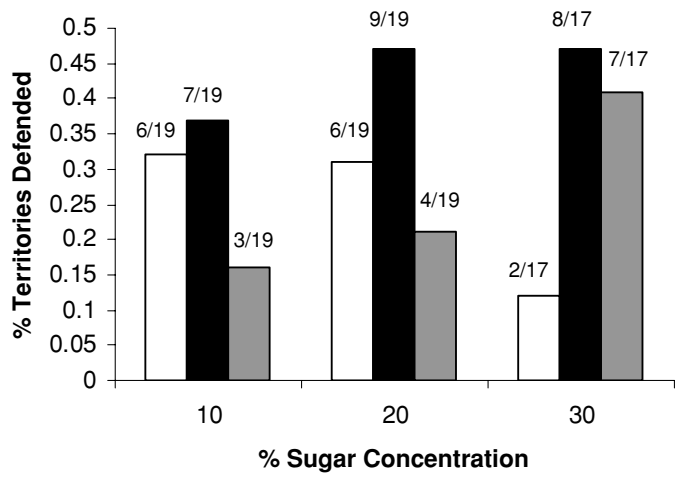

Fig. 1. Percent of territories defended relative to resource quality. Most feeders were defended by $\mathrm{Ru}-$ fous Hummingbirds. White bars represent territories defended by male Broad-tailed Hummingbirds, and black and grey bars represent territories defended by male and female Rufous Hummingbirds, respectively.

times (Fig. 1), and most (38 of 52, or 73.1\%) were Rufous Hummingbirds. The three observation periods where no territorial behavior was observed were at feeders with $10 \%$ sucrose solutions.

The number of intruders increased significantly as sucrose concentrations increased $(10 \%$ vs. $20 \% N=35, \chi^{2}{ }_{1}=19.2, P<0.0001 ; 10 \%$ vs. $30 \% N=33, \chi^{2}{ }_{1}=42.7, P<0.0001$; $20 \%$ vs. $30 \% N=36, \chi^{2}{ }_{1}=277.1, P<$ 0.001 ; Table 1). Because intruders were usually chased, the number of chases also increased as sucrose concentration increased $(10 \%$ vs. $20 \%$ $N=35, \chi^{2}{ }_{1}=25.7, P<0.0001 ; 10 \%$ vs. $30 \%$ $N=33, \chi^{2}{ }_{1}=58.0, P<0.0001 ; 20 \%$ vs. $30 \%$ $N=36, \chi^{2}{ }_{1}=36.1, P<0.0001$; Table 1).

The average chase was longest in duration at feeders with $30 \%$ sucrose solutions and shortest at feeders with $10 \%$ sucrose solutions $(10 \%$ vs. $20 \% N=34, \chi^{2}{ }_{1}=43.6, P<0.001 ; 10 \%$ vs. $30 \% N=32, \chi^{2}{ }_{1}=74.1, P<0.001$; $20 \%$ vs. $30 \% N=36, \chi^{2}{ }_{1}=20.5, P<0.001$; Table 1). The most common response of territory owners, regardless of species, to an intruder was chasing. Territory holders responded with chip calls and hovering along with a chase more often at feeders with $20 \%$ and $30 \%$ sucrose solutions than at feeders with $10 \%$ sucrose solutions (10\% vs. $20 \% N=166, \chi^{2}{ }_{1}=43.0, P<$ $0.0001 ; 10 \%$ vs. $30 \% P<0.0001, N=280$, $\chi^{2}{ }_{1}=27.9, P<0.0001 ; 20 \%$ vs. $30 \% N=$ 410, $\chi^{2}{ }_{1}=0.03, P=0.85$; Fig. 2 ). 
Table 1. Mean number of intruders, chases, and chase length per observation period at sites with feeders containing $10 \%, 20 \%$, and $30 \%$ sucrose solutions.

\begin{tabular}{lcrrr}
\hline Variable & $\begin{array}{c}\text { Sucrose } \\
\text { concentration }(\%)\end{array}$ & Mean \pm SE & $N$ & Range \\
\hline Number of intruders & 10 & $3.8 \pm 1.4$ & 19 & $0-22$ \\
& 20 & $15.1 \pm 2.4$ & 19 & $3-37$ \\
Number of chases & 30 & $27.5 \pm 4.3$ & 17 & $7-79$ \\
& 10 & $2.6 \pm 0.9$ & 19 & $0-12$ \\
Average chase length (s) & 20 & $11.6 \pm 2.6$ & 19 & $2-43$ \\
& 30 & $21.1 \pm 3.0$ & 17 & $4-53$ \\
& 10 & $1.9 \pm 0.4$ & 19 & $0-4.7$ \\
& 20 & $3.4 \pm 0.3$ & 19 & $2.0-5.4$ \\
& 30 & $4.2 \pm 0.2$ & 17 & $2.8-6.2$ \\
\hline
\end{tabular}

Although intruders were typically chased, hummingbirds only uttered chip calls, hovered, or both during 119 of 754 observations (15.8\%). Rufous Hummingbirds were more likely to respond to intruders with just chip calls and hovers (106 of 119 instances, or $89.1 \%$ ). The number of chip calls and amount of hovering without chasing increased as the sucrose concentration increased ( $10 \%$ vs. $20 \% N=30, \chi^{2}{ }_{1}=10.9$, $P=0.001 ; 10 \%$ vs. $30 \% N=92, \chi^{2}{ }_{1}=50.1$, $P<0.0001 ; 20 \%$ vs. $30 \% N=116, \chi^{2}{ }_{1}=$ 13.4, $P=0.0003$; Fig. 2).

\section{DISCUSSION}

Broad-tailed Hummingbirds defended feeders of all sucrose concentrations throughout the study, but were almost completely excluded from the feeders with $20 \%$ and $30 \%$ sucrose concentrations after arrival of Rufous Hummingbirds. Although Dunford and Dunford (1972) reported that a male Broad-tailed Hummingbird defended a territory against a male Rufous Hummingbird, migrating Rufous Hummingbirds usually displace resident Broad-tailed Hummingbirds (Kodric-Brown and Brown 1978, Calder 1993).

Powers and Conley (1994) and Sandlin (2000) suggested that, in the presence of a dominant hummingbird species, subordinate species shift foraging preferences from high- to lowquality food patches in lieu of participating in energetically costly aggressive interactions. In my study, Broad-tailed Hummingbirds shifted their defense activity from the feeders with $20 \%$ and $30 \%$ sucrose concentrations to those

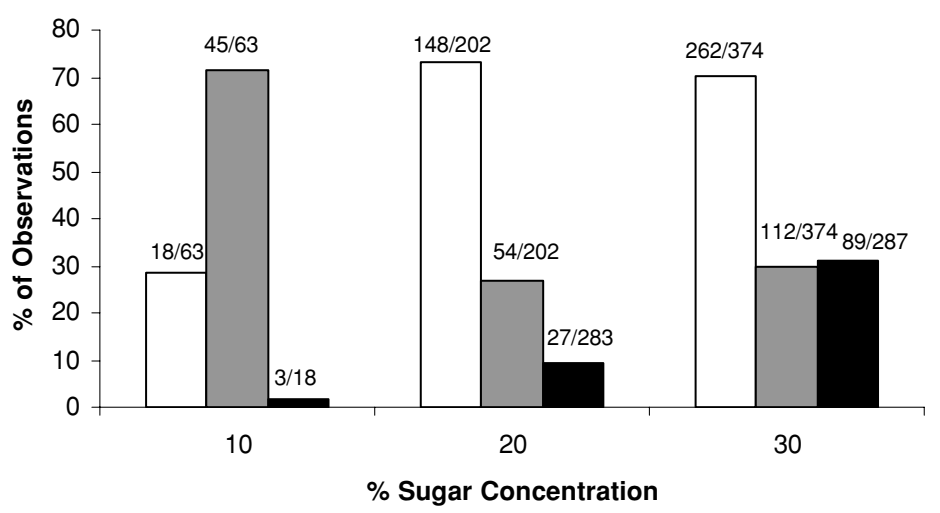

Fig. 2. Use of chip calls and hovering behavior relative to resource quality. Chip calls and hovering behaviors were added to chases more often at high concentration feeders. White bars show the number of chases with chip calls and hovering added. Gray bars show the number of chases without chip calls or hovering. Black bars show the number of interactions involving chip calls and hovering without chasing. 
with $10 \%$ sucrose concentrations after Rufous Hummingbirds arrived. This shift may have been due to the increased energetic costs of defending higher quality feeders as more birds arrived in the area. Alternatively, Dearborn (1998) proposed that there is a "cost of engagement" in aggressive encounters. As the cost of engagement increases, so do the risks of pursuing an interaction. Male Broad-tailed Hummingbirds may have shifted to feeders with $10 \%$ sucrose concentrations in the postreproductive period to avoid the costs of engaging in an aggressive interaction with dominant Rufous Hummingbirds.

Both Broad-tailed and Rufous hummingbirds exhibited more defensive behavior at feeders with high concentrations of sucrose than at feeders with lower concentrations. Chases were longest at high quality feeders and were more often supplemented with chip calls or hovering than chases at low quality feeders. Chase duration may have increased as sucrose concentration increased because intruders were more persistent at high quality feeders or because territory holders were more aggressive in defending higher quality sites. Either way, these results support the hypothesis that the intensity of defense reflects resource quality. Similarly, Camfield (2003) studied the display behavior of male Broad-tailed Hummingbirds and found that high quality sites received more visits from females and males defending these sites had higher display rates than males defending low quality sites.

I found that the number of intruding hummingbirds increased as territory quality increased. This trend was also shown for Black-chinned (Archilochus alexandri) and Blue-throated (Lampornis clemenciae; Powers and McKee 1994) hummingbirds and for Anna's Hummingbirds (Marchesseault and Ewald 1991). In my study, the number of chases, chip calls, and hovers also increased with territory quality. These results were expected because high quality sites yield a higher energetic return for the territory defender and, potentially, for the intruding individual.

Kodric-Brown and Brown (1978) suggested that, in the presence of an intruder, territorial hummingbirds first utter chip calls and display (by flashing their throat gorget) and, if the intruder is not repelled, they will begin a chase. I found the opposite; the default response of territory owners was to chase the intruder. Chip calls were often added to supplement a chase, but were rarely used alone. Similarly, Ewald and Bransfield (1987) studied Black-chinned and Anna's hummingbirds and concluded that chip calls were used to intensify defense, not as a precursor to a chase.

Rufous Hummingbirds in my study were more likely than Broad-tailed Hummingbirds to utter chip calls in response to intruders and not chase them. Because Rufous Hummingbirds are dominant to Broad-tailed Hummingbirds, uttering chip calls may provide sufficient warning and require less energy than chasing. Similarly, Ewald and Bransfield (1987) found that dominant Anna's Hummingbirds defended territories from subordinate Blackchinned Hummingbirds using chip calls rather than chases to save energy.

Some limitations of my study design may have affected interpretation of the results. It is possible that higher quality individuals established territories at higher quality sites. The increased level of defense observed at high quality feeders could reflect differences between individuals and may have been influenced only indirectly by resource value. Also, because I was unable to identify individuals, I could not quantify the rate of turnover of territory holders at each site. Differences in turnover at high and low quality sites could have influenced defensive behavior. Despite these limitations, it was still apparent that hummingbirds occupying high quality territories used different defensive behaviors than those occupying low quality territories.

Because my study involved the use of artificial feeders, the behavior of hummingbirds at natural feeding sites may differ. It may be obvious to an intruder that a territory with a feeder has an unnaturally rich food supply (Dearborn 1998). The presence of an augmented food source might change the behavior of an intruder and may also affect defensive behaviors of territory holders. Despite these potential issues, this type of study is useful in furthering our understanding of the mechanics and economics of hummingbird territorial behavior.

\section{ACKNOWLEDGMENTS}

I thank J. Edgar for her invaluable assistance in the field, the Rocky Mountain Biological Laboratory for permitting me to use their facilities, B. Low, J. Foufopoulos, K. Martin, S. Wilson, and anonymous reviewers for suggestions 
on earlier drafts of this manuscript, and K. Welch for help with statistical analyses. Support for this study was provided by the Lee R. G. Snyder Memorial Fund, the University of Michigan School of Natural Resources and Environment Alumni Incentive Fund, and Rackham Discretionary Funds at the University of Michigan.

\section{LITERATURE CITED}

ARMSTRONG, D. P. 1992. Use of sugar-water feeders to supplement energy availability to honeyeaters for experimental tests. Emu 92: 170-179.

Brown, J. L. 1964. The evolution of diversity in avian territorial systems. Wilson Bulletin 76: 160-169.

CALDER, W. A. 1993. Rufous Hummingbird (Selasphorous rufus). In: The birds of North America, No. 53 (A. Poole and F. Gill, eds.). The Academy of Natural Sciences, Philadelphia, and The American Ornithologist's Union, Washington, D.C.

$\longrightarrow$, AND L. L. CALDER. 1992. Broad-tailed Hummingbird (Selasphorous platycercus). In: The birds of North America, No. 16 (A. Poole and F. Gill, eds.). The Academy of Natural Sciences, Philadelphia, and The American Ornithologist's Union, Washington, D.C.

Calder, W. A., N. M. Waser, S. M. Hiebert, D. W. INOUYE, AND S. Miller, . 1983. Site-fidelity, longevity, and population dynamics of broad-tailed humming birds: A ten-year study. Oecologia 56:359364.

CAmfield, A. F. 2003. Quality of food source affects female visitation and display rates in male Broadtailed Hummingbirds. Condor 105: 603-606.

Carpenter, F. L., D. C. Paton, And M. A. Hixon. 1983. Weight gain and adjustment of feeding territory size in migrant hummingbirds. Proceedings of the National Academy of Sciences 80: 7259-7263.

DEARBORN, D. C. 1998. Interspecific territoriality by a Rufous-tailed Hummingbird (Amazilia tzacatl): effects of intruder size and resource value. Biotropica 30: 306-313.

Diggle, P. J., K. Y. Liang, AND S. L. Zeger. 1994. Analysis of longitudinal data. Clarendon Press, Oxford Science Publications, Oxford, UK.

DunFORD, C., AND E. DUNFORD. 1972. Interspecific aggression of resident Broad-tailed and migrant Rufous hummingbirds. Condor 74: 479.

EWALD, P. W., AND R. J. BRANSfiELD. 1987. Territory quality and territorial behavior in two sympatric species of hummingbird. Behavioral Ecology and Sociobiology 20: 285-293.

, AND F. L. CARPENTER. 1978. Territorial response to energy manipulations in the Anna's Hummingbird. Oecologia 31: 277-292.

Feinsinger, P., and S. B. Chaplin. 1975. On the relationship between wing disc loading and foraging strategy in hummingbirds. American Naturalist 109: 217-224.

Gardner, W., E. P. Mulvey, and E. C. Shaw. 1995. Regression analysis of counts and rates: poisson, overdispersed poisson, and negative binomial models. Psychological Bulletin 118: 392-404.

GASS, C. L. 1979. Territory regulation, tenure, and migration in Rufous Hummingbirds. Canadian Journal of Zoology 57: 914-923.

JOHNSGARD, P. A. 1997. The hummingbirds of North America, 2nd ed. Christopher Helm Publishers Ltd., London, UK.

Kodric-Brown, A., AND J. H. BROWN. 1978. Influence of economics, interspecific competition, and sexual dimorphism on territoriality of migrant Rufous Hummingbirds. Ecology 59: 285296.

Krebs, J. R., AND N. B. DAvies. 1993. An introduction to behavioural ecology, 3rd ed. Blackwell Scientific Publications, Oxford, UK.

Kuban, J. F., And R. L. Neill. 1980. Feeding ecology of hummingbirds in the highlands of the Chisos Mountains, Texas. Condor 82: 180-185.

Marchesseault, L., AND P. W. Ewald. 1991. Effect of territory quality on intrusion rate in nonbreeding hummingbirds. Behavioral Ecology and Sociobiology 28: 305-308.

POWERS, D. R. 1987. Effects of variation in food quality on the breeding territoriality of the male Anna's Hummingbird. Condor 89: 103-111.

$\longrightarrow$, AND T. M. CONLEY. 1994. Field metabolic rate and food consumption of two sympatric hummingbird species in southeastern Arizona. Condor 96: 141-150.

, AND T. MCKEE. 1994. The effect of food availability on time and energy expenditures of territorial and non-territorial hummingbirds. Condor 96: 1064-1075.

Sandlin, E. A. 2000. Cue use affects resource subdivision among three coexisting hummingbird species. Behavioral Ecology 11: 550-559.

SAS InSTITUTE InC. 2001. SAS/STAT user's guide. Release 8.2. SAS Institute Inc., Cary, NC. 